\title{
Üst Solunum Yolu Enfeksiyonu Geçiren Çocuklarda Tamamlayıcı ve Alternatif Tedavi Uygulamalarının İncelenmesi
}

\author{
Yurdagül HAZIR*, Gülçin BOZKURT**
}

$\ddot{O} z$

Giriş: Hemşireler üst solunum yolu enfeksiyonu geçiren çocuklarda kullanılan tamamlayıcı alternatif tedavi yöntemlerinin etkisini bilmeli, ebeveynler ve toplumu bilgilendirmelidir. Amaç: Üst solunum yolu enfeksiyonu geçiren çocuklarda kullanılan, tamamlayıcı ve alternatif tedavi uygulamalarını incelemektir. Yöntem: Tanımlayıcı tipteki araştırma, Mayıs-Aralık 2017 tarihleri arasında, İstanbul'un bir ilçesine bağlı, bir Aile Sağlığı Merkezinde yürütülmüştür. Araştırmanın örneklemini bu Aile Sağlı̆̆ Merkezinde üst solunum yolu enfeksiyonu tanısı almış 236 çocuğun ebeveyni oluşturmuştur. Veriler araştırmacı tarafindan literatür taranarak hazırlanan anket formu ile elde edilmiştir. Bulgular: Çalışma grubundaki ebeveynlerin \%95.8'i anne ve yaş ortalaması $33.38 \pm 6.56$ idi. Çocuk üst solunum yolu enfeksiyonu geçirdiğinde, ebeveynlerin \%86'sının tamamlayıcı ve alternatif tedavi uyguladığı belirlenmiştir. Ebeveynlerin \%92.1'i ilaç tedavisinden önce tamamlayıcı alternatif tedavi yöntemlerini kullanmaktadır. Ebeveynlerin \%95.1'i tamamlayıcı alternatif tedavi yöntemlerinden yararlandığını bildirmiştir. Ateşi düşürmek için ebeveynlerin \%68.6'sı tamamlayıcı alternatif tedavi-yöntemlerini kullanmaktadır. Ebeveynlerin öksürük (\%66.9) ve boğaz ağrısı (\%41.1) için sıklıkla bitki çayları verdiği belirlenmiştir. Annenin eğitimi arttıkça tamamlayıcı ve alternatif tedavi kullanma oranının azaldığı saptanmıştırr $(\beta=.32)$. Sonuç: Üst solunum yolu enfeksiyonu geçiren çocukların ebeveynlerinin büyük çoğunluğu tamamlayıcı ve alternatif tedavi uygulamaktadır. Ebeveynler çoğunlukla tamamlayıcı alternatif tedavi yöntemlerini ilaç tedavisinden önce kullanmaktadır. Ebeveynlerin eğitimi arttıkça tamamlayıcı ve alternatif tedavi kullanma oranları düşmektedir.

Anahtar Sözcükler: Solunum, Enfeksiyon, Tamamlayıcı ve Alternatif Tedavi, Çocuk.

\section{Investigation of Complementary and Alternatıve Treatment Practıces in Children with Upper Respiratory Tract Infection}

Background: Nurses should know the effects of complementary and alternative treatment methods used in children with upper respiratory tract infections, and should inform parents and society. Objectives: This study aim examine the complementary and alternative medicine used in children with acute upper respiratory infection. Methods: The descriptive study was conducted between May and December 2017 in a family health center in Istanbul. The sample of the study was the parent of 236 children who were diagnosed with upper respiratory tract infection in this Family Health Center. The data were collected by a researcher's questionnaire. Results: In this study $95.8 \%$ of parents were mothers and the mean age was $33.38 \pm 6.56$. When the child had upper respiratory tract infection, it was determined that $86 \%$ of the parents applied complementary and alternative treatment. $92.1 \%$ of the parents use complementary and alternative treatment methods before drug treatment. $95.1 \%$ of parents reported using complementary and alternative treatment methods. $68.6 \%$ of parents use complementary and alternatıve treatment methods to reduce fever. It was observed that parents frequently gave herbal teas for cough (66.9\%) and sore throat (41.1\%). As the education of the mother increased, the rate of complementary and alternative treatment decreased $(\beta=.32)$. Conclucion: it was determined that the majority of parents had complementary and alternative treatments when the child had upper respiratory tract infections. The majority of parents use complementary and alternative treatment methods prior to drug treatment. As parents' education increases, the use of complementary and alternative treatment decreases.

Key Words: Respiratory, Infection, Complementary and Alternative Treatment, Child.

\section{Geliș tarihi: 27.04.2019 Kabul tarihi: 19.05.2020}

$\mathrm{S}$ olunum yollarının ağız ve burundan glotise kadar olan bölümü (burun mukozası, nazofarenks, orofarenks, orta kulak, sinüsler, tonsiller ve epiglot) üst solunum yolları, bu bölgede ortaya çıkan enfeksiyonlarda üst solunum yolu enfeksiyonları (ÜSYE) olarak kabul edilmektedir (1). Çocuklarda en sık görülen hastalıklar üst solunum yolu enfeksiyonlarıdır. Bu hastalıkların çocuklarda \%30-40 oranında özellikle kış aylarında görüldüğü ve kendiliğinden iyileşebilen hastalıklar olduğu bilinmektedir $(2,3)$.

Çocuklar ÜSYE geçirdiğinde, hastalığı tedavi etmek, çocuğu rahatlatmak için modern tıp yöntemleri veya modern tıp dışında ki yöntemler sıklıkla kullanılmaktadır. Modern tıp dışındaki tedavi yöntemleri Tamamlayıcı ve Alternatif Tedavi (TAT) yöntemleri kapsamında ele alınmaktadır. Tamamlayıcı tedavi, modern tıbba yardımcı olarak hastanın rahatlaması, bağışıklık sisteminin güçlenmesi, hastanın psikolojisinin düzelmesi gibi amaçlarla uygulanan tedavi yöntemleridir. Alternatif tedavi ise, modern tıbbın yerine kullanılan geleneksel tedavi uygulamalarını kapsamaktadır $(4,5)$.

Dünyada ve ülkemizde TAT yöntemlerinin kullanımı giderek artmaktadır (4). Dünya Sağlık Örgütü’ne göre Afrika'da $\% 80$, Kanada'da \%70, Avusturalya'da \%48, Amerika'da \%42, Belçika'da \%38 ve Fransa'da \%49 oranında TAT kullanılmaktadır $(6,7)$. Uluslararası literatürde TAT yöntemlerinin kullanıldığı hastalıklara yönelik ülke çapında nüfusa dayalı yapılmış birçok çalışma bulunmaktadır. Avrupa ve Amerika'da yapılan çalışmalarda çocuklarda TAT kullanım oranının \%1.870 olduğu bildirilmektedir $(8,9)$.

Türkiye'de hastaların kullandığı yöntemleri gizlemesi ve yanlış bilgi vermesi nedeniyle gerçek TAT kullanma oranları bilinmemekle birlikte, farklı yayınlarda \%9-93.7 arasında değişen oranlarda kullanıldığı bildirilmektedir (10-12). Ülkemizde özellikle; kanser, diyabet, epilepsi, bronşiyal astım ve üst solunum yolu enfeksiyonlarında TAT'ların sık kullanıldığı bildirilmektedir (13).

Doğal ve zararsız olduğu düşünülen TAT'lar kullanımının kolay olması, invaziv girişim gerektirmemesi, ucuz olması ve kolay ulaşılır olması nedeniyle yaygın kullanılmaktadır $(14,15)$. Ayrıca sağlık hizmetlerinin yetersizliği, bilimsel gerçeklere inanmama, sosyo-kültürel özelikler, önyargılar, dini inanışlar, ilaçların yan etkilerinden korkma gibi nedenlerle modern tıp yerine TAT daha çok kullanılmaktadır $(5,14)$.

* Uzm. Hem., Nurtepe Aile Sağlığı Merkezi, İstanbul. E-posta: yrdgl-hzr@ hotmail.com ORCID: 0000-0002-7523-4501 **Doç. Dr., İstanbul Üniversitesi Cerrahpaşa Sağlık Bilimleri Fakültesi, Ebelik Bölümü, İstanbul. E-posta: gbozkurt@istanbul.edu.tr ORCID: 0000-0002-85282232 
Geleneksel olarak kullanılan birçok TAT yönteminin güvenli olmadığına dikkat çekilmektedir (10). Yaygın kullanılmasına rağmen TAT kullanmaya bağlı olası yan etkiler konusunda bilgiler yetersizdir. Literatürde TAT'ların bilinçsiz bir şekilde kullanılmasının, geleneksel tedavilerle etkileşerek tedavi sonucunu etkilediği veya yan etkilere yol açtığı bildirilmektedir $(6,11,13,16,17)$.

Çocuklarda TAT'ların kullanımı hakkında yeterli klinik çalışma bulunmamaktadır. Çocuk sağlığı açısından sık kullanılan TAT uygulamalarının bilinmesi toplum sağlığının korunması açısından son derece önemlidir (17). Çocuk hemşireleri; ÜSYE geçiren çocuklarda kullanılan TAT yöntemlerinin etkisi, riskleri ve modern tedavi yöntemleri ile etkileşimleri konusunda bilgi sahibi olmalı, TAT kullanan çocukları saptamalı, ebeveynler ve toplumu bilgilendirmelidir.

\section{Araştırma Soruları}

- ÜSYE geçiren çocuklarda TAT uygulama oranı nedir?

- ÜSYE geçiren çocuklarda hangi TAT yöntemleri kullanılmaktadır?

- ÜSYE geçiren çocuklarda TAT tercihlerini etkileyen faktörler nelerdir?

Araştırma, ÜSYE geçiren çocuklarda kullanılan tamamlayıcı ve alternatif tedavi yöntemlerini incelemek amacı ile yapılmıştır.

\section{Araştırmanın Tipi}

Nicel olarak tasarlanan araştırma, tanımlayıcı ve kesitsel tiptedir.

\section{Araştırmanın Yapıldı̆̆ Yer ve Tarihi}

Mayıs-Aralık 2017 tarihleri arasında İstanbul'da bir Aile Sağlı̆̆ı Merkezinde yürütüldü. Aile sağlı̆̆ı merkezinde bulunan altı birimde; toplam iki ebe, dört hemşire, altı aile hekimi ve bir hizmetli personel görev yapmaktadır. Bu merkezde; hasta muayeneleri, aile planlaması, aşılama, gebe-lohusa takibi, bebek-çocuk takibi ve izlemi, ev ziyareti, çeşitli laboratuvar tetkikleri, kanser taraması, eğitim, enjeksiyon ve pansuman hizmetleri verilmektedir.

\section{Araştırmanın Evreni ve Örneklemi}

Araştırmanın evrenini çalışmanın yürütüldüğü İstanbul'da bir Aile Sağlığı Merkezinden alınan bilgiye göre 2016 yılında bu merkezde, üst solunum yolu enfeksiyonu tanısı alan 10.000 çocuk olduğu görüldü. Araştırma örneklemi hesaplanırken 2016 yılında üst solunum yolu enfeksiyonu tanısı aldığı belirlenen çocukların ebeveynleri çalışmanın evrenine kabul edilmiştir. GPOWER 3.0 istatistik programında iki grupta (TAT kullanan ve kullanmayan) 0.05 anlamlılık, \%95 güç ve orta etki büyüklügüunde (0.5) çalışma için gerekli örneklem büyüklüğü 176 olarak belirlenmiştir. Araştırmanın verilerinin toplandığı dönemde veri kaybı olabileceği göz önünde bulundurularak 236 ebeveyne ulaşıldı. Bu ebeveynler araştırmanın örneklemini oluşturdu.

\section{Veri Toplama Araçlart}

Veriler araştırmacılar tarafindan literatür $(12,14,18)$ taranarak hazırlanan, 39 adet sorudan oluşan anket formu kullanılarak toplandı. Anket formu; ailelerin sosyo-demografik özellikleri, yaşanılan fiziki çevre, kullanılan TAT uygulamaları ve yaklaşımlarını kapsamaktadır. Anket formuna çocuk sağlığı hastalıkları hemşireliğinde beş uzmanın önerileri doğrultusunda son hali verilmiştir.

\section{Verilerin Toplanması}

Araştırma verileri araştırmacıların biri tarafından haftanın üç günü (salı, çarşamba, cuma), aile sağlığ1 merkezine giderek, araştırmaya katılmayı kabul eden ebeveynlerle anket formu yüz yüze görüşme yöntemi ile doldurulmuştur. Görüşme 10-15 dakika sürmüştür.

\section{Verilerin Değerlendirilmesi}

Araştırma sonunda elde edilen veriler SPSS 21.0 paket programında, parametrik ve nonparametrik tanımlayıcı istatistiksel analizler kullanılarak değerlendirildi. Tanımlayıcı verilerin analizinde sayı ve yüzde, değişkenlerin birbiri ile karşılaştırılmasında Pearson ki-kare, Yates ki-kare ve Fisher ki-kare analizleri, anlamlı çıkan değişkenlerle TAT kullanımı arasındaki ilişki Spearman korelasyon analizi ile, anlamlı çıkan değişkenlerin TAT kullanma durumunu yordama düzeyi lojistik regresyon analizi, değişkenler arasında çoklu bağıntı olup olmadığ 1 , değişkenlerin regresyon modeline dahil edilip edilmeyeceğini belirlemek için tolerans ve VIF analizi kullanılmış, tolerans değeri 0.2 ve VIF değeri 10'un altında olan değişkenler regresyon modeline dahil edilmiştir. İstatistiksel anlamlılık düzeyi 0.05 kabul edilmiştir.

\section{Araştırmanın Etik Yönü}

Etik kurul izni; araştırmanın yürütülebilmesi için, Okan Üniversitesi Etik Kurulu'ndan etik kurul (Tarih/Sayı:20.04.2017/82) ve İstanbul Halk Sağlığı Müdürlüğü’nden (Tarih/Sayı: 28.04.2017/ 64222187-030.03) kurum izni alınmıştır. Araştırma süresince Helsinki Bildirgesi kurallarına uyulmuş, araştırmaya katılan tüm ebeveynlere araştırmanın amacı açıklanmıştır. Araştırma sonuçlarının kimlik bilgileri verilmeden bilimsel amaçla yayınlanabileceği konusunda bilgi verilerek sözlü ve yazılı onamları alınmıştır.

Kurum izni: Çalışmanın Aile Sağlığı merkezinde yürütülebilmesi için İstanbul Halk Sağlığı Müdürlüğü’nden yazılı izin alınmıştır.

\section{Bulgular}

Çalışma grubunu ÜSYE tanısı almış 236 çocuğun ebeveyni oluşturdu. Çalışma grubundaki ebeveynlerin \%95.8'inin (n=226) anne olduğu, annelerin yaş ortalamasının $33.38 \pm 6.56$ ve babaların yaş ortalamasının ise $35.30 \pm 6.66$ olduğu belirlendi. Ailelerin \%92.8'i $(n=219)$ çekirdek aile ve \%47.5'inin $(n=112)$ gelirinin giderine eşit olduğu saptandı. Çocukların \%45.3'ünün $(\mathrm{n}=107)$ ayda bir-iki defa hastalandığı ve \%7.2'sinin $(\mathrm{n}=17)$ kronik bir hastalığı (\%4.3'ü astım ve \%2.9'unun böbrek yetmezliği, hipotroidi, biotinaz eksikliği ve epilepsi) olduğu görüldü. Çocuklar ortalama $5.04 \pm 3.69$ yaşında (\%39.8’u 1-3 yaş aralığında) ve \%53.8 (n=107)'isi erkek idi. Çalışma grubundaki; çocukların cinsiyeti, yaş grubu, hastalanma sıklığ 1 , kronik 
Araştırma

hastalığının olması, çocuk sayısı, aile tipi, annenin yaşı, eğitimi ve çalışma durumu gibi demografik değişkenlere göre ebeveynlerin ÜSYE TAT kullanması açısından istatistiksel olarak anlamlı bir fark saptanmadı $(\mathrm{p}>.0,05)$.

Tablo 1. Üst Solunum Yolu Enfeksiyonlarında TAT Uygulamaları (N=236)

\begin{tabular}{lc}
\hline & $\mathbf{n}(\boldsymbol{\%})$ \\
\hline ÜSYE'de TAT uygulama & $203(86)$ \\
Uygulayan & $33(14)$ \\
Uygulamayan & $173(73.3)$ \\
\hline TAT yöntemlerini tercih nedenleri* & $129(54.7)$ \\
Tıbbi yöntemlerin faydası olmadığı/ilaç kullanmayı istemediği için & $39(16.5)$ \\
Kolay erişilebilir olduğu için & $30(12.7)$ \\
Aile bireyleri/tanıdıklar kullanmasını istediği için & $24(10.2)$ \\
Hastanelerde çok beklediği için & $5(2.1)$ \\
Ucuz olduğu için & $193(95.1)$ \\
Bağışıklı̆̆ güçlendirdiği için & $10(4.2)$ \\
\hline TAT uygulamalarından yararlanma (n= 203) & $187(92.1)$ \\
Yararlanan & $12(5.9)$ \\
Yararlanmayan & $4(2.0)$ \\
\hline TAT uygulama zamanı (n = 203) & $192(94.6)$ \\
İlaç tedavisinden önce & $11(5.4)$ \\
İlaçlar ile birlikte & \\
İlaçlara cevap almadı̆̆ında & $155(76.4)$ \\
\hline TAT yöntemlerini tekrar kullanmayı düşünme (n= 203) & $12(5.9)$ \\
Düşünen & $36(17.7)$ \\
Düşünmeyen & \\
\hline TAT yöntemlerini başkasına tavsiye etme (n= 203) & \\
Tavsiye eden & \\
Tavsiye etmeyen & \\
Bilmeyen &
\end{tabular}

*Birden çok yanıt verilmiştir.

Ebeveynlerin \%86'sının çocuğu ÜSYE geçirdiğinde TAT uyguladığı, \%73.3'ünün tıbbi yöntemlerin faydası olmadığ1 ve ilaç kullanmak istemediği için TAT'1 tercih ettiği, \%95.1'inin TAT uygulamalarından yararlandığ 1 ve \%92.1'inin TAT'1 ilaç tedavisinden önce uyguladığı saptandı. TAT uygulayan ebeveynlerin \%76.4'ünün başkasına da tavsiye ettiği ve \%68.6'sının TAT ile ilgili bilgi kaynaklarının aile büyükleri ve akraba olduğu belirlendi (Tablo 1).

Çocuğu ÜSYE geçirdiğinde ebeveynlerin öncelikle \%73.3'ünün (n=173) evdeki ilaçları kullandığı, \%66.9'unun $(n=158)$ TAT yöntemlerini uyguladığ $1, \% 36.9$ 'unun $(n=87)$ doktora götürdüğü ve \%3'ünün (n=7) dua ettiği belirlendi (Tablo 2).

Tablo 2. Üst Solunum Yolu Enfeksiyonları Semptomlarında Uygulanan TAT (N=236)

\begin{tabular}{lc}
\hline & $\mathbf{n}(\boldsymbol{\%})$ \\
\hline Ateşi olduğunda öncelikle yapılanlar* & $67(28.4)$ \\
Doktora götüren & $174(73.7)$ \\
Doktora danışmadan ateş düşürücü veren & $6(2.5)$ \\
Doktora danışmada antibiyotik veren & $162(68.6)$ \\
TAT yöntemlerini uygulayan & $207(87.7)$ \\
\hline Ateşi düşürmek için yapılanlar* & $65(27.5)$ \\
Soğuk uygulama/1lı duş yaptıran & $8(3.4)$ \\
Sirkeli su ile vücudu silen & $44(18.6)$ \\
Bitki çayları içiren & $215(91.1)$ \\
\hline Öksürüğü kesmek/azaltmak için yapılanlar* & $82(34.7)$ \\
Doktora götüren & $11(4.7)$ \\
Bitki çayları /bitkisel karışım içiren & \\
Bal-pekmez veren & \\
Öksürük şurubu veren & $95(40.3)$ \\
\hline Boğaz ağrısını gidermek için yapılanlar * & $97(41.1)$ \\
Doktora götüren & $10(4.2)$ \\
Bitki çayları içiren & $59(25)$ \\
Gargara yaptıran & \\
Ballı süt, zencefilli bal, pekmez yediren & \\
\hline
\end{tabular}




\begin{tabular}{lc}
\hline Burun tıkanıklı̆̆ını gidermek için yapılanlar* & $79(33.5)$ \\
Doktora götüren & $113(47.9)$ \\
Burun lavajı & $6(2.5)$ \\
Aspiratör ile aspire eden & $28(11.9)$ \\
Buhar uygulayan & $8(3.4)$ \\
Diğer (6 kişi nane yağı, 2 kişi viksi burun kenarına sürmüş) & $155(65.7)$ \\
\hline Kulak ağrısını gidermek için yapılan uygulamalar* & $40(16.9)$ \\
Doktora götüren & $10(4.2)$ \\
Anne sütü damlatan & $6(2.5)$ \\
Soğan suyu damlatan & $8(3.4)$ \\
Zeytinyağı, ozon yağı, gliserin damlatan & \\
Kulağının üzerine sıcak havlu koyan & \\
\hline
\end{tabular}

*Birden çok yanıt verilmiştir.

Çocuklarının ateşi olduğunda ebeveynlerin \%73.7'sinin doktora danışmadan ateş düşürücü verdiği, \%87.7'sinin ateşi düşürmek için çocuğa soğuk /1lık duş aldırdığı ve öksürüğü kesmek için \%66.9'unun bitki çayı verdiği (1hlamur, anason çayı, nane limon, hatmi çiçeği çayı, rezene çayı, yeşil çay, adaçayı, elma, tarçın) saptandı (Tablo 2).

Ebeveynlerin sıklıkla boğaz ağrısını gidermek için \%41.1'inin bitki çayı verdiği (1hlamur, nane limon), burun tıkanıklığını gidermek için \%47.9'unun burun lavajı uyguladığı ve kulak ağrısında \%16.9'unun kulağa anne sütü damlattığı görüldü (Tablo 2).

Tamamlayıcı ve Alternatif Tedaviden yararlanan ebeveynlerin \%96.9'unun, yararlanmayanların ise \%50'sinin TAT'1 tekrar kullanmayı düşündüğü görüldü. Ebeveynlerin TAT uygulamasından yararlanma durumuna göre tekrar TAT kullanmayı düşünme durumları arasında istatistiksel olarak anlamlı bir fark saptanmıştır ( $\mathrm{p}<.000)$. TAT bir kez kullanma (OR:1.93) yeniden TAT kullanmayı düşünmeyi 1.93 artırmaktadır.

TAT uygulamasından yararlanan ebeveynlerin \%89.6'sı, yararlanmayanların ise \%66.7'si diğer çocuklarında da TAT kullandığı saptandı.

Tamamlayıcı ve Alternatif Tedaviden yararlanan ebeveynlerden \%79.3'ünün, başkasına TAT kullanmayı tavsiye ettiği, \%20.7'sinin ise tavsiye etmediği belirlendi. Ebeveynlerin kullandığı TAT'dan yararlanma durumuna göre başkasına TAT kullanmayı tavsiye etme durumları arasında istatistiksel olarak anlamlı bir fark saptandı ( $<<.001)$. TAT fayda görme (OR:3.96) TAT kullanmayı tavsiye etme durumunu 3.96 kat arttırdı.

Tablo 3. Anlamlı Bulunan Değişkenler ile TAT Kullanma Durumunu Yordama Düzeyi

\begin{tabular}{|c|c|c|c|c|c|c|c|c|}
\hline \multirow[t]{2}{*}{ Değişkenler } & & & & & & & \multicolumn{2}{|c|}{$\% 95 \mathrm{CI}$} \\
\hline & $\mathbf{B}$ & SE & Wald & Df & Sig. & $\operatorname{Exp}(B)$ & Lower & Upper \\
\hline Birey sayıs1 & .302 & .266 & 1.293 & 1 & .255 & 1.353 & .804 & 2.277 \\
\hline Anne eğitimi & -1.113 & .423 & 6.908 & 1 & .009 & .329 & .143 & .754 \\
\hline $\begin{array}{l}\text { Çocuk odası } \\
\text { olmas1 }\end{array}$ & .777 & .619 & 1.578 & 1 & .209 & 2.176 & .647 & 7.317 \\
\hline -2Log likelihood & 170.532 & $\begin{array}{c}\text { Cox \& } \\
\text { Snell R } \\
\text { Square } \\
\end{array}$ & .083 & $\begin{array}{c}\text { Nagelkr } \\
\text { ke R } \\
\text { Square }\end{array}$ & .150 & & & \\
\hline \multicolumn{9}{|c|}{ Hosmer and Lemeshow Test } \\
\hline Chi-square & 918 & Df & 6 & Sig. & .819 & & & \\
\hline
\end{tabular}

Hosmer ve Lemeshow testi sonucunda modelin uyumlu ve anlamlı olduğu belirlenmiştir. Modeldeki üç değişken (ailedeki birey sayısı, anne eğitimi ve çocuğun odasının olması) TAT kullanma durumunu \%15 açıklamaktadır. Değişkenler tek tek incelendiğinde ise TAT kullanımını etkileyen tek anlamlı değişkenin anne eğitimi olduğu, annenin eğitiminin artmasının TAT kullanım oranını azalttığı, annenin üniversite eğitimi almasının TAT kullanımını $(\beta=.329)$ R2: \%32.9 azalttı̆̆ı saptanmıştır (Tablo 3).

\section{Tartışma}

Son yıllarda dünyada ve ülkemizde TAT kullanımı giderek artmaktadır. Çocuklarda solunum yolu enfeksiyonlarında TAT yaygın kullanıldığı birçok çalışmada gösterilmiştir (9,19-21). Türkiye'de hastaların kullandığı yöntemleri gizlemesi, yanlış bilgi vermesi ve araştırmaların yetersiz olması nedeniyle TAT kullanma oranları bilinmemektedir (13).

Araştırma grubumuzdaki ebeveynlerin \%86'sının çocuğu ÜSYE geçirdiğinde TAT uyguladığı belirlendi (Tablo 1). Pitetti ve ark. (2001) Pittsburg'da çocuk acil servisine başvuran 525 ebeveynin \%12'sinin solunum sistemi sorunlarında en az bir çeşit TAT yöntemi kullandığını saptamıştır (9). Ülkemizde yapılan çalışmalarda TAT'ın ÜSYE sık kullanıldı̆̆ 1 (19-21), çocuklarda TAT kullanılma sıklığının \%18-95 arasında değiştiği bildirilmektedir (22). Topaloğlu ve ark. (2013) solunum yolu enfeksiyonu tanısı alan 214 ebeveyni ile yaptığı çalışmada \%93.7'sinin, Aydın ve ark. (2015) 220 ebeveyn ile yaptığı çalışmada \%69.4'ünün TAT uyguladığını saptamıştır (18). ÜSYE geçiren çocuklarda TAT kullanma oranlarının yüksek olduğu söylenebilir.

Ebeveynlerin büyük çoğunluğunun (\%92.1) TAT'ları ilaç tedavisinden önce uygulamıştı (Tablo 1). Topaloğlu ve ark. 
(2013) ailelerin \%56.7'sinin ilaç tedavisinden önce TAT uyguladığını saptamıştır (12). İlaç tedavisinden önce bu kadar yüksek oranlarda TAT tercih edilmesi düşündürücüdür.

Çalışma grubundaki ebeveynlerin TAT ile ilgili bilgi kaynaklarının; çoğunlukla aile büyükleri, akrabalar (\%68.6), komşular ve arkadaşlar (\%32.6) ve internet/televizyon (\%27.1) olduğu belirlendi. Taşar ve ark. (2011) \%60, Giray Bozkaya ve ark (2009) \%68.9, Topaloğlu ve ark. (2013) \%69.4 oranlarında TAT yöntemlerini aile büyüklerinden ve akrabalardan öğrendiğini belirlemiştir (12,13,21). Ebeveynlerin TAT'ları aile büyüklerinden ve yakın çevrelerindeki kişilerden öğrendiği ve uygulamayı çoğunlukla annelerin yaptığı için anneler ve bilgi kaynağı olan aile büyüklerine birlikte eğitim verilmelidir.

Ebeveynlerin eğitim düzeyi arttıkça TAT kullanım sıklığının azaldığı belirlenmiştir. Benzer şekilde Taşar ve ark. (2011) ve Topaloğlu ve ark. (2013) eğitim düzeyi arttıkça ilaç dışı uygulamaları kullanma sıklığının azaldığını saptamıştır. Ebeveynlerin eğitim düzeyi arttıkça TAT daha bilinçli yaklaştıkları düşünülmektedir $(12,21)$.

Ebeveynlerin yaklaşık 3/4'ünün çocuğunun ateşi olduğunda doktora danışmadan ateş düşürücü verdiği ve \%68.6'sının doğru ve hatalı uygulamaları bir arada kullandığ belirlendi (Tablo 2). Ebeveynlerin yaklaşık 1/3'ünün ateşi olduğunda çocuğu sirkeli su ile sildiği tespit edildi. Çöl Araz (2013), acil servise başvuran ebeveynlerin ateşli çocuğa öncelikle 1lık uygulama yaptığ1 ve ateş düşürücü ilaç verdiğini saptamıştır (23). Tuncel ve ark. (2014) ebeveynlerin \%9.7'sinin ateşi düşürmek için sirkeli suyla silme, sirke içirme, biber sürme, kırmızı renkli şeylerden uzak durma gibi uygulamalar yaptığını belirlemiştir (24). Ateşi düşürmek için çocuğun giysilerinin çıkarılması, ılık su ile duş aldırılması ve ılık kompres uygulamanın doğru uygulamalar olduğu, soğuk su ile duş, soğuk kompres, sirkeli su, alkollü su ve kolonya ile silmenin hatalı uygulamalar olduğu bilinmektedir $(19,25)$. Araştırma grubundaki annelerin doktora danışmadan ateş düşürücü kullanılması ve sirkeli su ile çocuğu silme gibi hatalı uygulama oranlarının yüksek olması kaygı vericidir.

Çocuklarda ateşten sonra en sık görülen öksürük, genellikle kendiliğinden düzelen bir semptomdur (14). Ebeveynlerin öksürüğü olan çocuğa sıklıkla bitki çayı \%66.9 (1hlamur, anason çayı, nane limon, hatmi çiçeği çayı, rezene çayı, yeşil çay, adaçayı, elma, tarçın), bal veya pekmez \%34.7 ve bitkisel karışımlar \%24.2 verdiği saptandı (Tablo 2). Bülbül ve ark (2009) ebeveynlerin \%22.5'inin, Büyük ve ark. (2014) \%72,8'sinin öksürüğü olan çocuklara bitkisel ürünler verdiğini, Topaloğlu ve ark. (2013) \%30.6 oranında bal verdiğini belirlemiştir $(14,21,27)$. Tuncel ve ark. (2014) ebeveynlerin öksürükte (\%23.8) bitki çayları (1hlamur, hatmi çiçeği, tarçın, nane-limon, papatya), bal, pekmez, süt ve zeytinyağı içirme veya sürme, gazete ile ovma gibi uygulamalar yaptığını saptamıştır (24). Büyük ve ak. (2014) tarafından yapılan bir araştırmada balın öksürüğü kesmede etkili olmadığı, öksürük sıklığını azaltmada etkili olduğu belirlenmiştir (14). TAT yöntemleri çocuklarda zararlı yan etkilere, mevcut tedavinin yarım kalmasına ve tedavi süresini uzamasına neden olabilmektedir (21). Bitkisel ürünlerin yaygın kullanılması ve araştırma sonuçlarının sınırlı olması nedeniyle bu ürünlerin etkisinin araştırılması gerekmektedir.

Ebeveynlerin boğaz ağrısını gidermek için bitki çayları (\%41.1), bal ve pekmez (\%25) vermişti (Tablo 2). Aydın ve ark. (2015) ebeveynlerin boğaz ağrısında bitki çayı (\%60,1) ve bal verdiğini (\%25.5) belirlemiştir (18). Uğurlu ve ark. (2014) boğaz ağrısında bitki çayları (\%26.1) içirildiğini bulmuştur (26). Araştırmalarda kullanım oranları değişmekle beraber boğaz ağrısının giderilmesinde aynı içerikte TAT uygulamaların yapıldı̆̆ 1 görülmektedir.

Burun tıkanıklığını gidermek için araştırma grubunda ki ebeveynlerin \%47.9'unun sıklıkla okyanus suyu veya serum fizyolojik ile burun lavajı ve sıcak su buharı (\%11.9) uyguladığı görüldü. Çocuklarda burun tıkanıklığı en sık ÜSYE nedeniyle olmaktadır (27). Aydın ve ark. (2015) ebeveynlerin \%32.3'ünün burun tıkanıklığında burunu tuzlu su ile yıkadığını saptamıştır (18). Literatürde burun tıkanıklığında tuzlu su ile burun lavajının kronik ve alerjik sinüzitte yardımcı tedavi yöntemi olduğu, uygulama şekli ve sıklığının hala tartışmalı olduğu belirtilmektedir $(18,27)$. Burun tıkanıklığını gidermeye yönelik uygulamaların etkinliğinin deneysel çalışmalar ile irdelenmesi gerekmektedir.

Ebeveynlerin kulak ağrısını gidermek için anne sütü (\%16.9), soğan suyu (\%4.2), zeytinyağı, ozon yağı, gliserin (\%2.5) damlattığı ve kulağına sıcak havlu koyduğu (\%3.4) görüldü. Efe ve ark. (2012) Antalya'da 512 ebeveyn ile yaptığ1 çalışmada, çocuğun kulak ağrısını gidermek için \%30.3'ünün anne sütü, \%2.9'unun zeytinyağı, gliserin damlattığı veya gliserinli pamuk koyduğunu belirlemiştir (28). Etkinliği kanıtlanmayan TAT kullanımı tartışmalıdır.

Ebeveynlerin büyük çoğunluğu (\%95.1) TAT yöntemlerinden fayda gördüğünü belirtmiştir (Tablo 1). TAT yöntemlerini bir kez kullanmanın tekrar TAT kullanmayı 1.938 oranında arttırdığ 1 saptanmıştır. Literatürlerde TAT yöntemlerinin hastalığı tedavi etmediği, semptomları, korku ve kaygıyı azalttığ , hastaların motivasyonunu ve yaşam kalitesini arttırdığı bildirilmektedir (15). Toplumda bilinen TAT yöntemleri genellikle sözlü tavsiyeler ile nesiller boyu aktarılmaktadır. Çalışma grubumuzdaki ebeveynlerin \%76.4'ü TAT yöntemlerini başkalarına önereceğini belirtmişti. Regresyon analizinde modele alınan anlamlı değişkenler, tek tek incelendiğinde TAT kullanımını etkileyen tek anlamlı değişkenin anne eğitimi olduğu, annenin eğitiminin artmasının TAT kullanım oranını (R2: \%32.9) azalttığı görüldü (Tablo 3). Topaloğlu ve ark. (2013) TAT kullananların \%87.5'inin bu yöntemleri başkalarına da önereceğini belirtmektedir (12). TAT kullanım kolaylığı, doğal ve zararsız olduğunun düşünülmesi, invaziv girişim gerektirmemesi, ucuz olması ve kolay ulaşılır olması, sağlık hizmetlerinin yetersizliği, sosyo-kültürel özelikler, önyargılar, dini inanışlar, ilaçların yan etkilerinden korkma vb. nedenler ile yaygın kullanılmaktadır $(5,14,15)$. TAT yararlandığını düşünme ve başkalarına önerme oranlarının yüksek olması uzun yıllar bu yöntemlerin aktarımının süreceğini düşündürmektedir.

\section{Sonuçların Uygulamada Kullanımı}

Sonuçlar ÜSYE geçiren çocuklarda ebeveynlerin TAT kullanılma sıklığı ve tercih nedenlerinin anlaşılmasına, TAT kullanımına yönelik ebeveynler ve toplumun eğitilmesi konusundaki literatüre katkı sağlayacaktır. Elde edilen sonuçların, çocuk sağlığının geliştirilmesi için çocuk sağlığı alanında hizmet verenlere; çocuk sağlığı ve hastalıkları hemşireleri, halk sağlığı hemşireleri, hekimler ve politika yapıcılara ipucu sağlaması beklenmektedir. 


\section{Bilgilendirme}

Yazarların katkı oranı beyanı şu şekildedir: fikir ve kavram YH, GB; tasarım YH, GB; denetleme ve danışmanlık GB; veri toplama ve işleme YH; analiz ve yorum YH, GB; kaynak taraması YH; makalenin yazımı YH, GB; eleştirel düşünme YH, GB. Araştırma ile ilgili herhangi bir projeden ya da firmadan destek alınmamıştır. Araştırmanın bütçesi araştırmacılar tarafindan karşılanmıştır.

Yazarlar arasında herhangi bir çıkar çatışması yoktur. Ayrıca sorumlu olduğumuz araştırmada herhangi bir firma ile çıkar ilişkisi bulunmamaktadır.

Araştırmanın yapılabilmesi için bir üniversitenin girişimsel olmayan araştırmalar etik kurulundan 20.4.2017 Tarih 64222187-030.03 20 karar nolu izin alınmıştır.

\section{Kaynaklar}

1. Pettigrew MM, Gent JF, Pyles RB, Miller AL, Nokso-Koivisto J, Chonmaitree T. Viral-bacterial interactions and risk of acute otitis media complicating upper respiratory tract infection. Journal of Clinical Microbiology 2011;49(11):37503755 .

2. Arslan M, Şahin AE, Gülsever O, Güneş HŞ, Aldemir BA, Duran F ve ark. Çocuklarda viral ve bakteriyel üst solunum yolları enfeksiyonlarının ayırımında klinik skorlama. Family Practice and Palliative Care 2017;2(3):6-11.

3. Tosun E, Topaloğlu O, Yalçın A. Solunum yolu enfeksiyonları: antibiyotik kullanım oranı ve tedavi maliyeti. Türkiye Aile Hekimliği Dergisi 2008;12(1):25-30.

4. Lafçı D, Kaşıkçı MK. Yataklı sağlık kuruluşunda görev yapan sağlık personelinin tamamlayıcı ve alternatif tedavi yöntemlerini bilme ve kullanma durumları. Gümüşhane Üniversitesi Sağlık Bilimleri Dergisi 2014;3(4):1114-1131.

5. Özçelik G, Toprak D. Bitkisel tedavi neden tercih ediliyor. AnkMedJ 2015;15(2):48-58.

6. Polat G, Yıldırım G, Polat HH. Tamamlayıcı alternatif tıp ile ilgili gazete haberlerinin gazetecilik, halk sağlığı ve tıbbi etik boyutuyla değerlendirilmesi. IJHHS 2014;11(1):814-835.

7. World Heath Organization. Traditional stragey 2002-2005. Geneva, URL: http://www.wpro.who.int/health_technology/book_who_traditional_medicine_stragey_2002.pdf.16.Aralik.2017.

8. Medsen H, Andersen S, Nielsen R, Dolmer BS, Host A, Damkier A. Use of complemantary/alternative medicine among pediatric patients. Eur J Pediatr 2003; 162:334- 341.

9. Pitetti R, Singh S, Hornayak D, Garcia SE, Herr S. Complementary and alternative medicine use in children. Pediatric Emergency Care 2001; 17:165-169.

10. Cirık V, Efe E. Pediatri hemşireliğinde tamamlayıcı sağlık yaklaşımlarının önemi. HEAD 2017;14(2):144-149.

11. Çetin O. Eskişehir'de tamamlayıcı ve alternatif tıp kullanımı. Sosyoekonomi 2007;6(6):97-105.

12. Topaloğlu N, Yıldırım Ş, Tenkin M, Uludağ A, Özgen K. Türkiye'nin batısında solunum yolu enfeksiyonu geçiren çocuklarda alternatif tedavi uygulamaları. Guncel Pediatri 2013;11(1):23-26.

13. Giray Bozkaya Ö, Akgün İ, Birgi E, Çinkoğlu A, Gög K, Karadeniz D. Anne babaların çocuklarında uyguladıkları alternatif tıp yöntemleri. Tıp Fakültesi Dergisi 2008;22(3): 129-135.

14. Büyük ET, Güdek E, Kalaycı N. Annelerin öksürüğü olan çocuğa yaklaşımları. Gümüşhane Üniversitesi Sağlık Bilimleri Dergisi 2014;3(4):1019-1031.

15. Ceyhan D, Yiğit TT. Güncel tamamlayıcı ve alternatif tıbbi tedavilerin sağlık uygulamalarındaki yeri. DÜ Sağlık Bil Enst Derg 2016;6(3):178-189.

16. Jacobsson I, Jönsson AK, Gerdén B, Hägg S. Spontaneously reported adverse reactions in association with complementary and alternative medicine substances in Sweden. Pharmacoepidemiology and Drug Safety 2009;18(11):1039-1047.

17. Uzun MB, Aykaç G, Özçelikay G. Bitkisel ürünlerin yanlış kullanımı ve zararları. Lokman Hekim Dergisi 2014;4(3):15 .

18. Aydın D, Çiftçi EK, Kahraman S, Şahin N. Alternative treatment practices of mothers whose children had respiratory tract infection. JPR 2015;2(4): 212-217.

19. Araz N, Bulbul S. Use of complementary and alternative medicine in a pediatric population in southern. Turkey. CIM 2011;34(1):21-29.

20. Özturk C, Karayagız G. Exploration of the use of complementary and alternative medicine among Turkish children. $\mathrm{J}$ Clin Nurs 2008;17(19:2558-2564.

21. Taşar MA, Potur ED, Nursel K, Bostancı İ, Dallar Y. Düşük gelir düzeyine sahip ailelerin çocuklarına tamamlayıcı veya alternatif tıp uygulamaları: Ankara hastanesi verileri. Türkiye Çocuk Hastalıkları Dergisi 2011;5(2):81-88.

22. Özcebe H, Sevencan F. Çocuklarda tamamlayıcı ve alternatif tıbbı konu alan araştırmaların değerlendirilmesi. Çocuk Sağlığı ve Hastalıkları Dergisi 2009;52(4):183-194.

23. Çöl Araz N. Ailelerin ateşli çocuğa yaklaşımı: bilgi, tutum ve uygulamaları. Türkiye Çocuk Hastalıkları Dergisi 2013;1:27-32.

24. Tuncel T, Şen V, Kelekçi S, Karabel M, Şahin C, Uluca ve ark. Kronik hastalığı olmayan çocuklarda tamamlayııı ve alternatif tıp kullanımı. Türk Ped Ars. 2014; 49:148-53.

25. Öztürk Ö, Topan A, Ayyıldız T. Ateş şikayeti ile acil servise getirilen çocuklarda ateş olgularının değerlendirilmesi. HSP 2015;2(3):285-296.

26. Uğurlu E, Kalkım A, Sağkal T. 0-1 Yaş arası bebeklerde sık karşılaşılan ağrı durumları ve ailelerin yaklaşımları. Fırat Tıp Dergisi 2014;19(1):25-30. 
Araştırma

27. Bülbül SH, Turgut M, Köylüoğlu S. Çocuklarda tıp dışı alternatif uygulamalar konusunda ailelerin görüşleri. Çocuk Sağlığı ve Hastalıkları Dergisi 2009;52(4): 195-202.

28. Efe E, Öncel S, Yılmaz M. Kadınların diş, karın ve kulak ağrısı olan çocuklarına yaklaşımları. Ağrı 2012; 24(2): 69-76 